\title{
MONITORING THE DAMAGE OF EXTERIOR RENDERS CAUSED BY THE ENVIRONMENT
}

\author{
MONIKA ČÁCHOVÁ ${ }^{1}$, JAROSLAVA KOŤÁTKOVÁ ${ }^{2}$, DANA KOŇÁKOVÁ ${ }^{1}$, EVA VEJMELKOVÁ ${ }^{1}$, \\ MARTIN KEPPERT ${ }^{1}$, PAVEL REITERMAN ${ }^{2}$, JAROMÍR ŽUMÁR ${ }^{1}$ \& ROBERT ČERNÝ ${ }^{1}$ \\ ${ }^{1}$ Department of Materials Engineering and Chemistry, Faculty of Civil Engineering, Czech Technical University \\ in Prague, Czech Republic \\ ${ }^{2}$ Experimental Center, Faculty of Civil Engineering, Czech Technical University in Prague, Czech Republic
}

\begin{abstract}
Three renders commonly used in the Czech Republic on the exterior side of building envelopes are exposed for 2 years to the environmental conditions of the city of Prague. The effect of external environment on their possible damage is monitored using the measurement of a variety of material properties in selected time intervals. The experimental results do not show any significant deterioration of most parameters during the 2-year investigation period. The open porosity is found to decrease with time due to the continuing hardening processes. The mechanical properties are thus improved after 1 year of exposition and only little worsened after the second year. The changes in the pore structure also result in deceleration of water- and water-vapor transport and a slight increase of thermal conductivity. The obtained results will serve as reference data for finding a correlation between the accelerated laboratory tests and the behavior of analyzed materials in real building structures.

Keywords: basic physical properties, environmental effects, exterior plasters, liquid water transport, strength, thermal properties, water vapor transport.
\end{abstract}

\section{INTRODUCTION}

Plasters belong to the most common external surface layers of building envelopes in many European countries. They present a low-cost solution and their application requires only basic technological skills which are the most important arguments for their frequent use. They have been used since Ancient Rome; firstly as mixtures consisting of quicklime and pozzolanic additives. Nowadays, various types of binders, such as gypsum, gypsum-lime, magnesium, quicklime, hydraulic lime, lime-pozzolan, lime-cement or cement [1], are commonly used for that purpose. Cement- or lime-cement plasters have better strength, but their appearance on buildings might seem rough and unnatural. Therefore, their use for historical building is not recommended. They are appropriate for facades subjected to higher wear or moisture effects. Lime plasters are the most widely used form of surface finishing for reconstruction and maintenance of architectural heritage. They can be applied as pure lime plasters or plasters modified by organic or inorganic admixtures. By the addition of pozzolans in the mixture composition, their mechanical properties and resistance to deteriorating influences can be enhanced [1]. Currently, the most frequently used pozzolan in lime plasters is metakaolin, despite its high price [2-6], volcanic ashes, sedimentary rocks, crushed brick, ceramic powder, or different types of fly ashes are applied less often.

Plasters present the face of the majority of buildings and therefore are exposed to environmental deteriorative effects. In the conditions of Central Europe, the main deterioration mechanisms are physical and chemical. One of the main factors affecting their durability is 
the permeability of the material. Penetration of water into the plaster structure can in winter time result in severe damage caused by repeating cycles of freezing and thawing [7, 8]. Water often brings along dissolved sulfates, chlorides, or gaseous pollutants starting various deteriorating processes such as alkali-silica reaction, crystallization of salts, or carbonation $[9$, 10]. Therefore, the appropriate pore volume and pore size distribution is of great importance. The amount of pores in a plaster can be reduced by the incorporation of pozzolanic admixtures. Thanks to the pozzolanic reaction, which develops later in time, a denser microstructure is formed. On the other hand, if the plasters should have a lower density and still provide a good protection against moisture effects, hydrophobic and foaming agents are used [11-13].

In this paper, several plasters commonly used either in contemporary buildings or in building renovation works in the Czech Republic are analyzed. The time duration of the experiment is 2 years while testing a part of the specimens is performed after 1 year and the second part is subjected to the same tests after two years. Reference samples are tested as well, for the sake of comparison.

\section{MATERIALS}

Three different types of plasters, which are commonly used in the Czech Republic, were studied, namely a core plaster, a lightweight plaster and a redevelopment plaster (Table 1). The samples were prepared according to the recommendations of the producer (Baumit, s.r.o.). The water to dry substances ratio was determined for each plaster separately to get the same consistency, which was tested according to ČSN EN 1015-3 [14]. The flow was measured in two perpendicular directions until the values of $160 / 160 \mathrm{~mm}$ were reached. One set of studied plasters was subjected to the experiments just after the 28-days curing period (it is marked as "ref" in the subsequent sections), another two sets were exposed to the outside environment in a test facility located in the city of Prague and tested after 1 and 2 years after preparation. The upper horizontal surfaces of the specimens were covered so that the wind, rain, snow and sun radiation affected only the vertical surfaces, similarly as in their practical application on building site.

\section{RESULTS AND DISCUSSION}

\subsection{Basic physical properties}

The basic physical properties comprising the bulk density, $\rho_{\mathrm{V}},\left[\mathrm{kg} / \mathrm{m}^{3}\right]$, matrix density, $\rho_{\text {mat, }}\left[\mathrm{kg} / \mathrm{m}^{3}\right]$ and total open porosity, $\psi_{0},[\%]$ were measured by means of water vacuum saturation and helium pycnometry methods [15]. The measurements by water vacuum saturation method are summarized in Table 2, and the results obtained by helium pycnometry are given in Table 3.

The lightweight plaster marked as BT exhibited the lowest bulk density and highest open porosity, the core plaster BJ was on the opposite side in that respect. BJ exhibited a significant

Table 1: The studied plasters.

\begin{tabular}{llc}
\hline Material & \multicolumn{1}{c}{ Characteristic } & w/ds \\
\hline BJ & Baumit GrobPutz Maschinell - core plaster & 0.17 \\
BT & Baumit Thermo Putz - lightweight plaster with perlite & 0.40 \\
BP & Baumit Sanova - redevelopment plaster & 0.34 \\
\hline
\end{tabular}


Table 2: Basic physical properties of the studied plasters determined by water vacuum saturation method.

\begin{tabular}{llllllllll}
\hline & \multicolumn{3}{c}{$\rho_{\mathrm{v}}\left[\mathrm{kg} / \mathrm{m}^{3}\right]$} & \multicolumn{3}{c}{$\rho_{\text {mat }}\left[\mathrm{kg} / \mathrm{m}^{3}\right]$} & \multicolumn{3}{c}{$\Psi_{0}[\%]$} \\
\cline { 2 - 10 } Material & ref & 1 year & 2 years & ref & 1 year & 2 years & ref & 1 year & 2 years \\
\hline BJ & 1,606 & 1,659 & 1,689 & 2,552 & 2,563 & 2,398 & 37.1 & 35.3 & 29.6 \\
BT & 452 & 487 & 497 & 1,741 & 1,805 & 1,633 & 74.0 & 73.0 & 69.5 \\
BP & 1,118 & 1,134 & 1,146 & 2,284 & 2,250 & 2,112 & 51.1 & 49.6 & 45.8 \\
\hline
\end{tabular}

Table 3: Basic physical properties of the studied plasters determined by helium pycnometry.

\begin{tabular}{llllllllllll}
\hline & \multicolumn{3}{c}{$\rho_{\mathrm{v}}\left[\mathrm{kg} / \mathrm{m}^{3}\right]$} & \multicolumn{3}{c}{$\rho_{\text {mat }}\left[\mathrm{kg} / \mathrm{m}^{3}\right]$} & \multicolumn{3}{c}{$\psi_{0}[\%]$} \\
\cline { 2 - 12 } Material & ref & 1 year & 2 years & ref & 1 year & 2 years & ref & 1 year & 2 years \\
\hline BJ & 1,599 & 1,636 & 1,667 & 2,548 & 2,588 & 2,462 & 37.3 & 36.8 & 32.3 \\
BT & 455 & 492 & 501 & 1,805 & 1,849 & 1,686 & 74.8 & 73.4 & 70.3 \\
BP & 1,136 & 1,179 & 1257 & 2,314 & 2,384 & 2,352 & 50.9 & 50.6 & 46.6 \\
\hline
\end{tabular}

decrease in open porosity with time. The measurement by water vacuum saturation method after 2 years showed a $20 \%$ lower value, as compared to the initial value. For the other two plasters the decrease was lower, $10 \%$ for BP and only $6 \%$ for BT. This could be attributed to the continuing hardening processes. The helium pycnometry tests were in accordance with the results of water vacuum saturation measurements.

The pore-size characteristics were measured by mercury intrusion porosimetry. The experiments were carried out by Pascal 140 and Pascal 440 devices. The results in the form of cumulative and incremental pore size distribution curves are given in Figs 1 and 2, respectively. The cumulative pore size distribution curves showed after 1 year a decrease in pore volume over the whole pore size range analyzed. The pore size distribution curves revealed that the lightweight plaster had the highest amount of pores above $1 \mu \mathrm{m}$, that is, it contained a majority of capillary pores. The other two plasters had much lower pore volume in that region. The changes of pore size distribution with time were similar for all three plasters.

\subsection{Mechanical properties}

The measurement of bending strength was made by a common three-point bending test on $40 \times 40 \times 160 \mathrm{~mm}$ specimens, using an MTS 100 device. The compressive strength was determined by an EU 40 device on the fragments left over after the bending strength measurement. The experiments were performed according to the standard ČSN EN 1015-11 [16]. The dynamic modulus of elasticity was measured by a Proceq Pundit Lab ultrasonic device equipped by $54 \mathrm{kHz}$ probes on specimens with dimensions $40 \times 40 \times 160 \mathrm{~mm}$.

Figures $3-5$ show that the redevelopment plaster BP exhibited the best performance, as for the mechanical properties. Both compressive and bending strength had the highest values after one year of exposition and then slightly decreased. Apparently, during the first year the hardening processes (hydration or carbonation) indicated already in the porosity measure- 


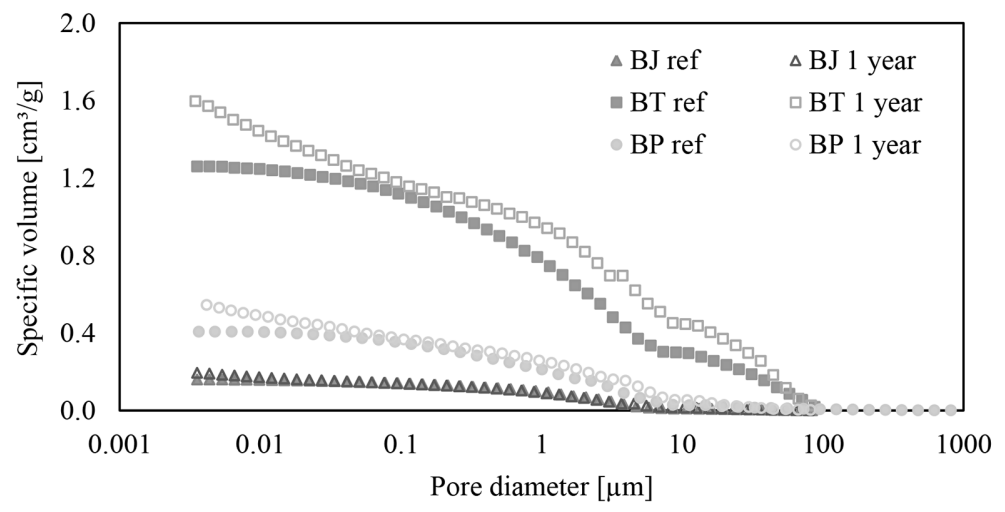

Figure 1: Cumulative pore size distribution.

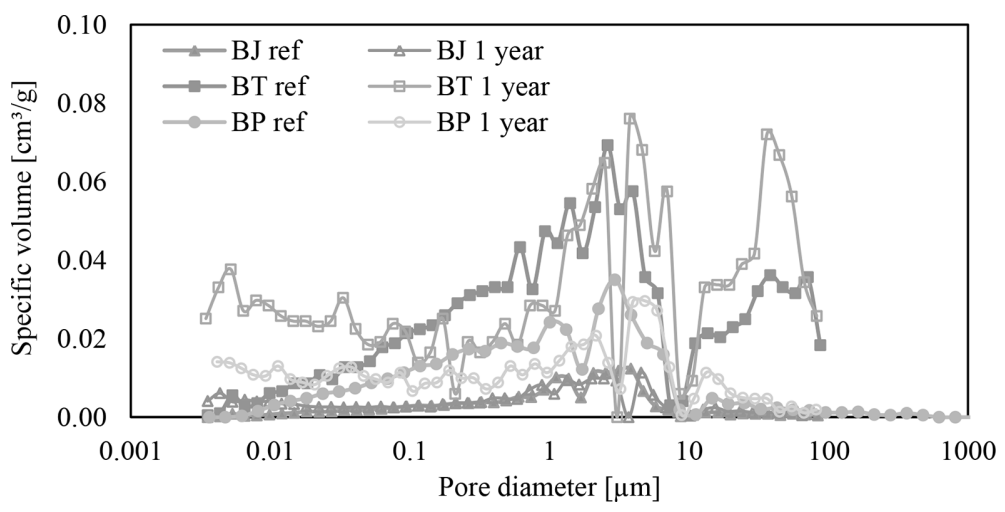

Figure 2: Incremental pore size distribution.

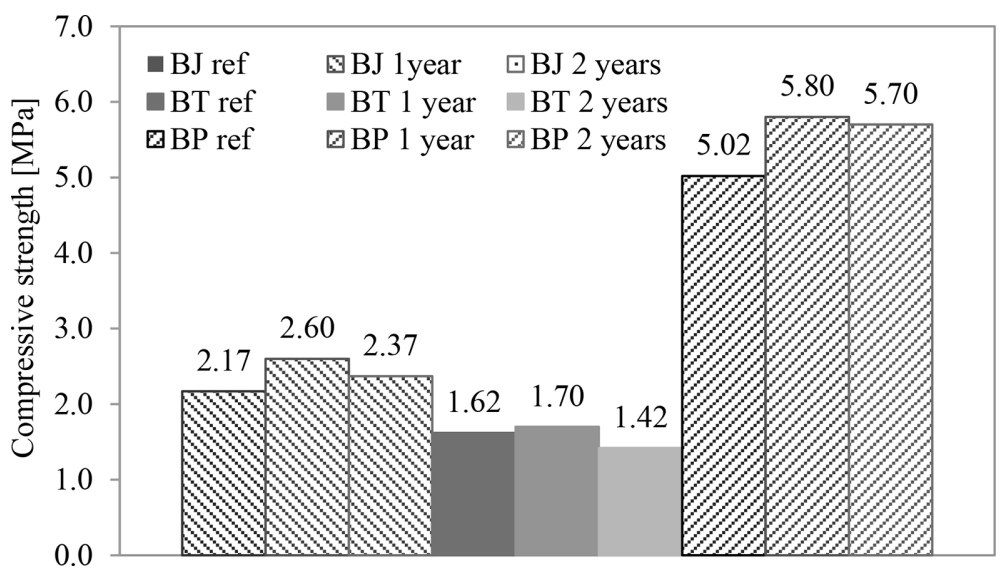

Figure 3: Compressive strength of studied plasters. 


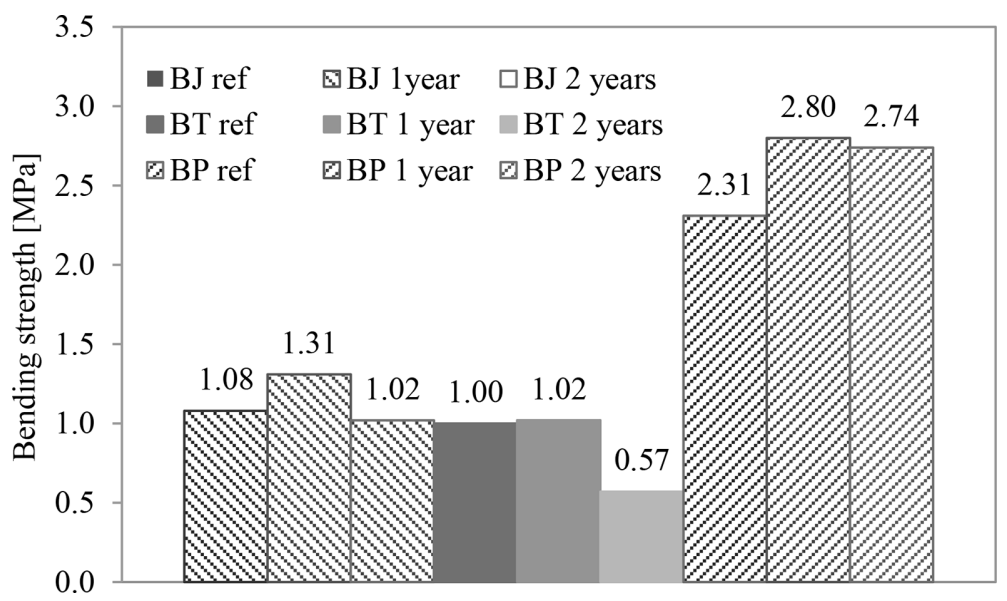

Figure 4: Bending strength of studied plasters.

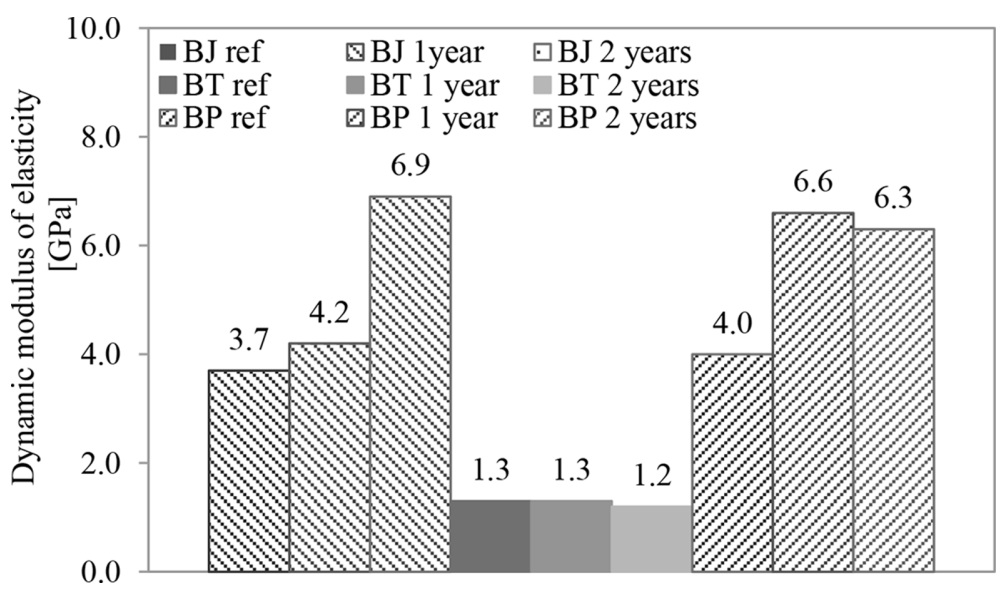

Figure 5: Dynamic modulus of elasticity of studied plasters.

ments were still in progress, while later the deteriorating effects of the surrounding environment prevailed.

\subsection{Frost resistance}

The freeze/thaw resistance tests were performed according to ČSN 722452 [17]. The samples were submerged in water and exposed to 10 freezing and thawing cycles. The freezing cycle lasted 8 hours at $-15^{\circ} \mathrm{C}$ and thawing took another 8 hours at $+20^{\circ} \mathrm{C}$. After each cycle the samples were subjected to compressive strength test. The decrease in strength was then considered the indicator of the freeze-thaw deterioration. The worst frost resistance (Table 4) was found for the lightweight plaster, as the compressive strength decreased by $59 \%$. The core plaster and redevelopment plaster behaved better, the decrease was $23 \%$ and $27 \%$, respectively. 
Table 4: Frost resistance of studied plasters.

\begin{tabular}{lcccccc}
\hline & \multicolumn{5}{c}{ Compressive strength [MPa] } \\
\cline { 2 - 7 } Material & 0. cycle & 1. cycle & 3. cycle & 5. cycle & 7. cycle & 10. cycle \\
\hline BJ & 2.24 & 1.64 & 1.66 & 1.66 & 1.49 & 1.33 \\
BT & 1.35 & 1.12 & 1.08 & 1.04 & 0.86 & 0.55 \\
BP & 5.62 & 5.51 & 5.10 & 4.87 & 4.36 & 4.13 \\
\hline
\end{tabular}

\subsection{Water transport and storage properties}

\subsubsection{Transport of water vapor}

The water vapor diffusion resistance factor $\mu[-]$ was measured by the dry- and wet cup methods [18]. The cups were placed in a controlled climatic chamber with $50 \%$ relative humidity. In the dry cup method, silica gel was used, while in the wet cup method, water was placed in the cup. The results are presented in Table 5. The highest $\mu$ values were observed for the core plaster BJ, followed by the redevelopment plaster, while the lightweight plaster BT was the material most open to water vapor transport. The water vapor diffusion resistance increased with time in all cases. The lightweight plaster showed the highest increase, $25 \%$ for the dry-cup and $44 \%$ for the wet cup method, the lowest growth was found for the core plaster BJ.

\subsubsection{Transport of liquid water}

The water absorption coefficient $A\left[\mathrm{~kg} / \mathrm{m}^{2} \mathrm{~s}^{1 / 2}\right]$ and moisture diffusivity $\kappa\left[\mathrm{m}^{2} / \mathrm{s}\right]$ were determined in a water absorption experiment [19]. The studied plaster specimens $(50 \times 50 \times$ $50 \mathrm{~mm}$ ) were immersed 1-2 mm into water and their mass was recorded by a digital balance [20].

The highest values of water absorption coefficient (Table 6) were observed for the core plaster BJ but on the other hand, its decrease in time was the most pronounced for this material (25\% after 2 years of exposition, as compared to the initial value). The lightweight plaster exhibited a $22 \%$ decrease after 2 years, the redevelopment plaster showed an increase of $A$ after 1 year and then a slight decrease.

\subsubsection{Water vapor sorption}

The desiccator's method was used for the measurement of water vapor adsorption and desorption isotherms [21]. The test was carried out on $40 \times 40 \times 40 \mathrm{~mm}$ samples.

The obtained results are presented in Fig. 6. It can be seen that the lightweight plaster BT was the material most likely adsorbing moisture. It also exhibited the widest hysteresis between the water vapor adsorption and desorption curves. The core- and redevelopment plasters showed a much lower capability of water vapor sorption.

\subsection{Thermal properties}

The thermal conductivity $\lambda[\mathrm{W} / \mathrm{mK}]$ and specific heat capacity $c[\mathrm{~J} / \mathrm{kgK}]$ were determined by an ISOMET 2,114 device [22] working on the heat pulse principle. Thermal parameters of the studied plasters in dry state and water saturated state are given in Tables 7 and 8 . 
Table 5: Water vapor diffusion resistance factor $\mu[-]$ of studied plasters.

\begin{tabular}{lllllll}
\hline & \multicolumn{3}{c}{ Dry cup } & \multicolumn{3}{c}{ Wet cup } \\
\cline { 2 - 7 } Material & ref & 1 year & 2 years & ref & 1 year & 2 years \\
\hline BJ & 19.7 & 21.3 & 22.9 & 8.6 & 9.9 & 10.1 \\
BT & 9.2 & 10.2 & 12.3 & 3.9 & 5.1 & 7.0 \\
BP & 12.4 & 13.7 & 15.3 & 5.7 & 7.0 & 8.3 \\
\hline
\end{tabular}

Table 6: Liquid water transport parameters of studied plasters.

\begin{tabular}{lcccccc}
\hline & \multicolumn{3}{c}{$\mathrm{A}\left[\mathrm{kg} / \mathrm{m}^{2} \mathrm{~s}^{1 / 2}\right]$} & \multicolumn{3}{c}{$\kappa\left[\mathrm{m}^{2} / \mathrm{s}\right]$} \\
\cline { 2 - 7 } Material & ref & 1 year & 2 years & ref & 1 year & 2 years \\
\hline BJ & 0.120 & 0.113 & 0.090 & $9.92 \mathrm{E}-08$ & $1.13 \mathrm{E}-07$ & $9.31 \mathrm{E}-08$ \\
BT & 0.075 & 0.071 & 0.058 & $8.95 \mathrm{E}-09$ & $8.98 \mathrm{E}-09$ & $7.17 \mathrm{E}-09$ \\
BP & 0.037 & 0.051 & 0.049 & $5.31 \mathrm{E}-09$ & $5.56 \mathrm{E}-09$ & $2.50 \mathrm{E}-09$ \\
\hline
\end{tabular}

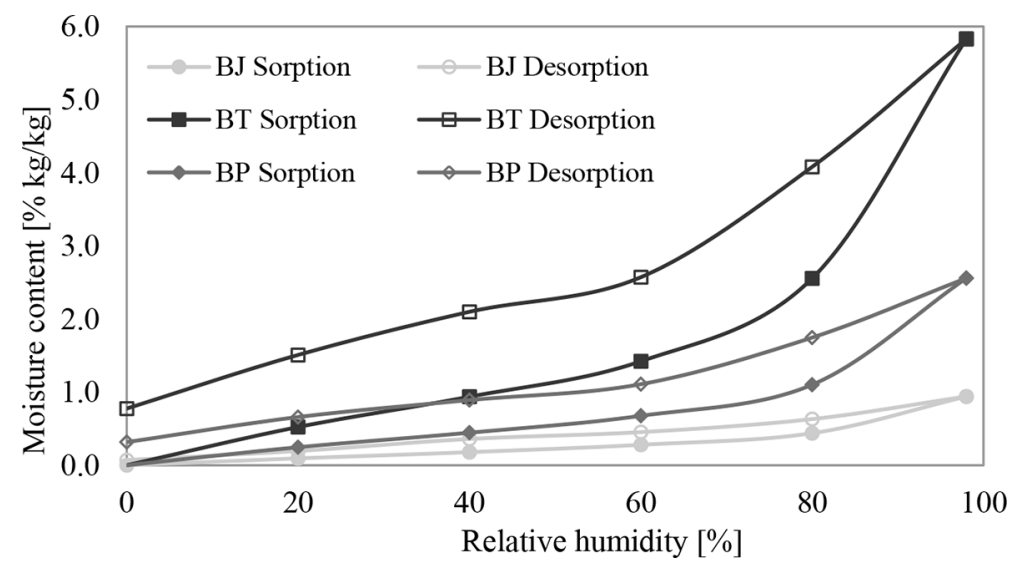

Figure 6: Adsorption and desorption isotherms of studied plasters.

Table 7: Thermal properties of studied plasters in dry state.

\begin{tabular}{lccccccc}
\hline & \multicolumn{3}{c}{$\lambda[\mathrm{W} / \mathrm{mK}]$} & \multicolumn{3}{c}{$\mathrm{c}[\mathrm{J} / \mathrm{kgK}]$} \\
\cline { 2 - 7 } Material & ref & 1 year & 2 years & ref & 1 year & 2 years \\
\hline BJ & 0.586 & 0.624 & 0.667 & 886 & 899 & 910 \\
BT & 0.099 & 0.104 & 0.111 & 927 & 948 & 1,004 \\
BP & 0.244 & 0.263 & 0.265 & 1,209 & 1,278 & 1,274 \\
\hline
\end{tabular}


Table 8: Thermal properties of studied plasters in water saturated state.

\begin{tabular}{lcccccc}
\hline & \multicolumn{3}{c}{$\lambda[\mathrm{W} / \mathrm{mK}]$} & \multicolumn{3}{c}{$\mathrm{c}[\mathrm{J} / \mathrm{kgK}]$} \\
\cline { 2 - 7 } Material & ref & 1 year & 2 years & ref & 1 year & 2 years \\
\hline BJ & 1.662 & 1.679 & 1.779 & 1,418 & 1,391 & 1,364 \\
BT & 0.670 & 0.742 & 0.723 & 2,852 & 2,809 & 2,736 \\
BP & 0.739 & 0.875 & 0.848 & 1,987 & 2,011 & 2,029 \\
\hline
\end{tabular}

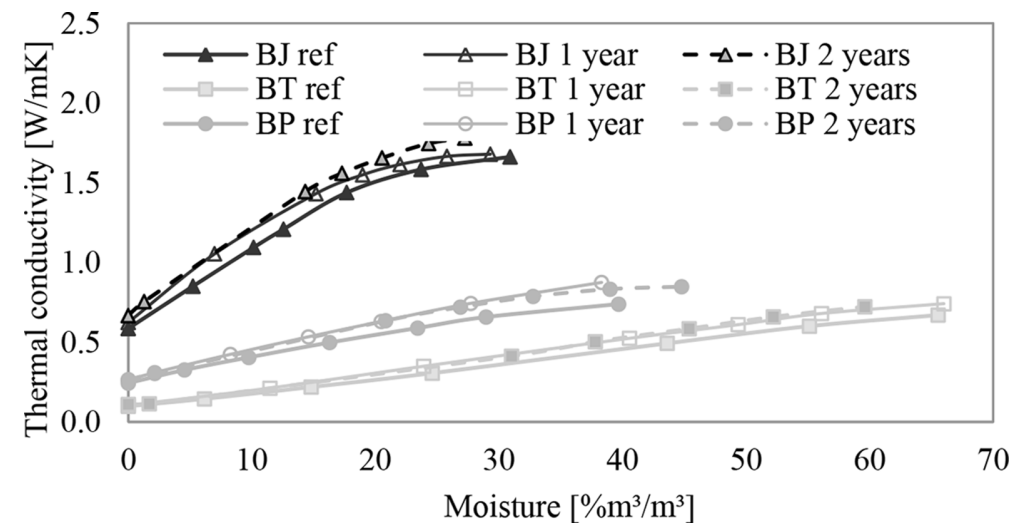

Figure 7: Thermal conductivity of studied plasters as a function of moisture content.

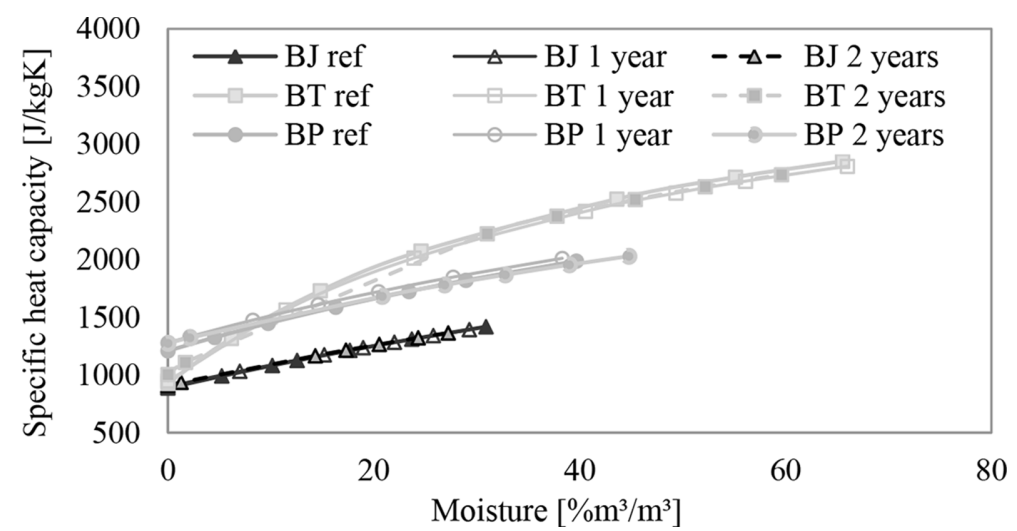

Figure 8: Specific heat capacity of studied plasters as a function of moisture content.

Apparently, after the exposure to external environment, the thermal conductivity of all plasters increased which was mainly due to the decreased porosity. The lightweight plaster BT exhibited the lowest thermal conductivity while the core plaster BJ showed the highest values. Figures 7 and 8 show that the thermal conductivity of all studied materials was strongly dependent on moisture content, in the case of BT the increase was even $85 \%$. 


\section{CONCLUSIONS}

The properties of three plasters commonly used in the Czech Republic were investigated. The analyzed specimens were exposed for 2 years to the outside environment in a test facility in Prague, where the effects of rain, snow, wind, sun radiation, and low temperatures on their possible damage were studied. The basic physical properties, mechanical properties, frost resistance, hygric and thermal properties of the analyzed materials were determined at first before exposition to the weather conditions, just after the 28-days curing period, and then after 1 and 2 years in the outside environment. The experimental results did not show any significant deterioration of most parameters during the 2-year investigation period. The open porosity was found to decrease with time due to the continuing hardening processes. The mechanical properties were improved after one year of exposition and only little worsened after the second year. The changes in the pore structure resulted also in deceleration of waterand water vapor transport and a slight increase of thermal conductivity.

\section{ACKNOWLEDGMENT}

This research has been supported by the Czech Science Foundation, under project No P105/12/G059.

\section{REFERENCES}

[1] Rovnaníková, P., Omítky, Chemické a technologické vlastnosti. STOP, Praha, 2002.

[2] Cabrera, J. \& Rojas, M.F., Mechanism of hydration of the metakaolin-lime-water system. Cement and Concrete Research, 31, pp. 177-182, 2001. http://dx.doi.org/10.1016/S0008-8846(00)00456-7

[3] Shvarzman, A., Kovler, K., Grader, G.S. \& Shter, G.E., The effect of dehydroxylation/amorphization degree on pozzolanic activity of kaolinite. Cement and Concrete Research, 33, pp. 405-416, 2003. http://dx.doi.org/10.1016/S0008-8846(02)00975-4

[4] Černý, R., Kunca, A., Tydlitát, V., Drchalová, J. \& Rovnaníková, P., Effect of pozzolanic admixtures on mechanical, thermal and hygric properties of lime plasters. Construction and Building Materials, 20, pp. 849-857, 2006.

http://dx.doi.org/10.1016/j.conbuildmat.2005.07.002

[5] Pernicová, R., Pavlíková, M. \& Černý, R., Effect of metakaolin on chloride binding in lime-based composites. Proceedings of Computational Methods and Experimental Measurements XIII, pp. 357-365, 2007. http://dx.doi.org/10.2495/CMEM070371

[6] Pavlík, Z., Vejmelková, E., Fiala, L. \& Černý, R., Effect of moisture on thermal conductivity of lime-based composites. International Journal of Thermophysics, 30 , pp. 1999-2014, 2009. http://dx.doi.org/10.1007/s10765-009-0650-y

[7] Kočí, J., Maděra, J., Rovnaníková, P. \& Černý, R., Hygrothermal performance of innovative renovation renders used for different types of historical masonry. WIT Transactions on the Built Environment, 118, pp. 683-693, 2011. http://dx.doi.org/10.2495/STR110571

[8] Kočí, V., Maděra, J. \& Černý, R., Exterior thermal insulation systems for AAC building envelopes: computational analysis aimed at increasing service life. Energy \& Buildings, 47, pp. 84-90, 2012. http://dx.doi.org/10.1016/j.enbuild.2011.11.030 
[9] Pavlíková, M., Pavlík, Z., Keppert, M. \& Černý, R., Salt transport and storage parameters of renovation plasters and their possible effects on restored buildings' walls. Construction and Building Materials, 25, pp. 1205-1212, 2011. http://dx.doi.org/10.1016/j.conbuildmat.2010.09.034

[10] Park, S., Kwon, S. \& Jung, S.H., Analysis technique for chloride penetration in cracked concrete using equivalent diffusion and permeation. Construction and Building Materials, 29, pp. 183-192, 2012. http://dx.doi.org/10.1016/j.conbuildmat.2011.09.019

[11] Lanzón, M. \& García-Ruiz, P.A., Evaluation of capillary water absorption in rendering mortars made with powdered waterproofing additives. Construction and Building Materials, 23, pp. 3287-3291, 2009.

http://dx.doi.org/10.1016/j.conbuildmat.2009.05.002

[12] Izaguirre, A., Lanas, J. \& Álvarez, J.I., Effect of water-repellent admixtures on the behaviour of aerial lime-based mortars. Cement and Concrete Research, 39, pp. 10951104, 2009. http://dx.doi.org/10.1016/j.cemconres.2009.07.026

[13] Tesárek, P., Rovnaníková, P., Kolísko, J. \& Černý, R., Properties of hydrophobized FGD gypsum. Cement Wapno Beton, 10, pp. 255-264, 2005.

[14] CSN EN 1015-3: Methods of test for mortar for masonry - Part 3: determination of consistence of fresh mortar (by flow table), Prague, 2007.

[15] ČSN EN 1015-10: Methods of test for mortar for masonry - Part 10: determination of dry bulk density of hardened mortar, Prague, 2000.

[16] ČSN EN 1015-11: Methods of test for mortar for masonry - Part 11: determination of flexural and compressive strength of hardened mortar, Prague, 2007.

[17] ČSN 72 2452: Testing of frost resistance of mortar, Prague, 2005.

[18] ČSN 1015-19: Methods of test for mortar for masonry - Part 19: determination of water vapour permeability of hardened rendering and plastering mortars, Prague, 2005.

[19] Kumaran, M.K., Moisture diffusivity of building materials from water absorption measurements. IEA annex 24 report T3-CA-94/01, Ottawa, 1994.

[20] ČSN EN 1015-18: Methods of test for mortar for masonry - Part 18: determination of water absorption coefficient due to capillarity action of hardened mortar, Prague, 2003.

[21] Roels, S., Carmeliet, J., Hens, H., Adan, O., Brocken, H., Černý, R., Pavlík, Z., Hall, C., Kumaran, K., Pel, L. \& Plagge, R., Interlaboratory comparison of hygric properties of porous building materials. Journal of Thermal Envelope and Building Science, 27, pp. 307-325, 2004.

http://dx.doi.org/10.1177/1097196304042119

[22] Applied Precision - ISOMET, [User manual], Bratislava, 1999. 